\title{
Work Related Clusters of COVID-19 in Muscat Governorate in Oman: Epidemiology \& Future Implications
}

\author{
Fatma Al Fahdi', Padmamohan J. Kurup², Lamya Al Balushi', Mohammed Amin1, \\ Balqees Al Siyabi', Mariam Al Kalbani' ${ }^{1}$, Haleema Al Ghazaili', Salwa Al Mashari², \\ Hanan Al Kindi ${ }^{3}$
}

\author{
${ }^{1}$ Disease Surveillance and Control, Directorate General of Health Services, Muscat Governorate, Ministry of Health, Muscat, \\ Oman \\ ${ }^{2}$ Directorate General of Disease Surveillance \& Control, Ministry of Health, Muscat, Oman \\ ${ }^{3}$ Primary Health Care, Directorate General of Health Services, Muscat Governorate, Ministry of Health, Muscat, Oman \\ Email: falfahdicom@gmail.com
}

How to cite this paper: Al Fahdi, F., Kurup, P.J., Al Balushi, L., Amin, M., Al Siyabi, B., Al Kalbani, M., Al Ghazaili, H., Al Mashari, S. and Al Kindi, H. (2021) Work Related Clusters of COVID-19 in Muscat Governorate in Oman: Epidemiology \& Future Implications. Open Journal of Epidemiology, 11, 135-151. https://doi.org/10.4236/ojepi.2021.112013

Received: March 19, 2021

Accepted: May 7, 2021

Published: May 11, 2021

Copyright ( 2021 by author(s) and Scientific Research Publishing Inc. This work is licensed under the Creative Commons Attribution International License (CC BY 4.0).

http://creativecommons.org/licenses/by/4.0/ (c) (i) Open Access

\begin{abstract}
Introduction: The coronavirus disease 2019 epidemic emerged in December 2019 and spread worldwide. Since workplaces are high-risk location for occupational exposure, understanding of the dynamics of COVID-19 clusters in occupational settings helps reduce the transmission of infectious disease in workplaces. This study presents an overview of the epidemiological characteristics of COVID-19 workplace clusters, preventive strategies adopted and outbreak responses undertaken in Muscat governorate. Materials and Methods: This is a descriptive study on the epidemiological characteristics of cases and distribution of workplace-related clusters of COVID-19 in Muscat Governorate in Oman. Results: A total of 36,798 COVID-19 cases were confirmed in Muscat from $24^{\text {th }}$ February to $31^{\text {st }}$ July 2020 in which $40.5 \%$ was belonging to clusters. Out of them $61 \%$ were Workplace-Dormitory clusters, predominantly expatriates. $78.6 \%$ of employees were symptomatic at time of examination. Fever and cough were the two most common symptoms reported in workplace related clusters. The number of affected employees ranged from 2 to 358 per cluster. Construction, retail, food, beverages, services, industrial manufacturing, oil \& gas and transportation were identified as most at risk settings. Within the cases in workplace-related clusters, there was significant higher prevalence of diabetes, hypertension and obesity among females compared to males as also Omani nationals compared to expatriates and smoking among expatriate males compared to Omani males. In conclusion, understanding the epidemiological characteristics of the affected cases in organization setting will assist the policymakers to understand pat-
\end{abstract}


terns of epidemiological spread and plan for robust interventions.

\section{Keywords}

COVID-19, Epidemiology, Clusters, Occupational, Workplace, Dormitories

\section{Introduction}

The coronavirus disease 2019 (COVID-19) that emerged in December 2019 was declared by the World Health Organization as public health emergency of international concern [1] on 30th January 2020 [2] and as pandemic in March 2020 [3]. Since flu pandemic of 1918, the current pandemic is the greatest public health risk caused by a respiratory virus with severe impact on all economies [1] [4].

Workers' safety, health, and well-being have been thrust into the spotlight during the COVID-19 pandemic. Since the beginning of this pandemic, many employees got infected with COVID 19, some developed serious disease resulting in some deaths. This facilitated easy transmission of infection to co-workers and their contacts [5]. Higher healthcare associated transmission risk being known health staff has better infectious disease protection and preparedness [6]. However, infections risk being less in other occupations, the workplaces and industries are less prepared or never realized the importance of infection disease control plan in the workplace [6]. In fact, workplaces are high risk location for occupational exposure to COVID-19 because of the gathering of many people in the same place, some jobs involve direct contact with public and some workers have direct exposure to workplace contamination [7]. An emerging pandemic as COVID-19 with less known details about mechanism of disease transmission and difficult early case detection, makes workers more susceptible to the disease [7] coupled with fear of exposure to co-workers with uncertain infectious status [5]. During the periods of lockdown, the health and safety of essential workers, who come into direct contact with the public, got severely affected due to uncertainty of others' infection statuses, adding lots of stress to those workers who must continue to go to a workplace while others stay at home [5].

According to the Centers for Disease Control (CDC) guidelines, the occupations were recognized as higher risk for exposure to COVID-19 included, health care workers, workers in cemeteries and the funeral houses, workers in airports, airlines, railways, subways and all public transports, border guards, solid waste and wastewater workers, dentists, makeup artists and employees who travel frequently [7]. Two groups of workers need special mention in COVID-19 pandemic context. First group is migrants' workers because of factors such as barriers in accessing healthcare, low coverage of insurance services in host country, higher mental stress due to isolation and quarantine, job loss fear as well as language barriers that lead to lack of health information about the disease and its 
seriousness and preventive and control measures [7]. Another important group is workers who are old, or have underlying chronic diseases like cardiovascular diseases, diabetes, respiratory disease and cancer, or workers prone for occupational lung diseases with high exposure to hazardous chemicals such as vapors and gases run severe course of the disease caused by COVID-19 [7]. Occupational risk, migrant status, high risk medical conditions, work settings are thus extremely important in the planning of any preventive and control measures for COVID-19 in the workplace [7].

A national strategic plan and standard processes were adopted for measures to be taken in workplace settings incorporating an audit mechanism and was implemented in Muscat Governorate [8] [9]. Guidelines for assessment for preparedness, risk communication and adoption of safe practices were implemented at country level and local level in pre-pandemic phase for the occupational settings [10]. This was followed by important national strategies during pandemic phase; closure of some non-essential workplaces, reduction of employees in workplaces, work from home, universal masking etc. [10]. Additionally, measures were taken to reduce spread of the virus in workplaces like identifying cases and clusters, isolating patients, tracing contacts, and preventing community transmission [8] [9] [10].

Many reports were published on the epidemiology of clusters of COVID-19 cases from many countries but only few reports provide comprehensive overview and burden of COVID-19 clusters in workplace settings and their dynamics [3] [11]. An understanding of the dynamics of COVID-19 clusters in occupational settings and review of the preventive steps taken, both at the workplace and regulatory levels to help reduce the transmission of infectious disease in workplaces will be timely lessons for future. This study presents an overview of the epidemiological characteristics of COVID-19 workplace clusters, preventive strategies adopted, outbreak responses undertaken in Muscat governorate and discusses the lessons learned providing insights for future pandemic preparedness planning. To our knowledge, this is the first study on epidemiological characteristics, distribution and dynamics of COVID-19 workplace-related clusters in Oman and Middle East area.

The study is based in Muscat Governorate, which is the capital of Oman with a population of 542,523 Omani and 759,917 expatriates (Table 1) [12]. Most of the country workforce is concentrated in Muscat Governorate $(171,810 / 751,831$ Omani, 574,110/1,406,976 expatriates) (Table 1) [12].

\section{Materials and Methods}

This is a descriptive study on epidemiology of workplace related clusters. We included data of all COVID-19 cases collected by the surveillance team in Muscat Governorate from $24^{\text {th }}$ February till $31^{\text {st }}$ July 2020, identified as belonging to clusters. Those cases with no information of belonging to cluster were excluded from analysis. 
Table 1. Population and workforce in Muscat Governorate as per census 2020.

\begin{tabular}{cccc}
\hline Wilayates & Omani & Expatriate & Total \\
\hline Bousher & 89,307 & 292,877 & 382,184 \\
Seeb & 257,809 & 220,708 & 478,517 \\
Mutrah & 39,099 & 191,782 & 230,881 \\
Amerat & 90,077 & 31,026 & 121,103 \\
Muscat & 19,548 & 11,769 & 31,317 \\
Qurayat & 46,683 & 11,755 & 58,438 \\
Grand Total in Muscat & 542,523 & 759,917 & $1,302,440$ \\
Workforce in Muscat governorate as per census 2020 & \\
Governmental sector & 66,839 & 21,290 & 88,129 \\
Non-Governmental sector & 104,971 & 552,820 & 657,791 \\
Total (in Muscat) & 171,810 & 574,110 & 745,920 \\
Total (in Oman) & 751,831 & $1,406,976$ & $2,158,807$ \\
\hline
\end{tabular}

\subsection{Definitions Used}

A confirmed COVID-19 case is one that met the relevant epidemiological history and clinical symptoms with a respiratory sample positive for SARS-CoV-2 by RtPCR test [13]. A cluster meant two or more confirmed cases within 14 days occurring either in one family, workplace, dormitories or an event lead to human-to-human transmission of COVID-19 where there is the possibility of interpersonal transmission due to close contact, or due to the possibility of infection through common exposure. A workplace related cluster refers to an aggregation of cases grouped in one particular workplace and or dormitory and by time.

\subsection{Data Source}

All suspect and confirmed cases of COVID-19 are entered in the mandatory notification system of Ministry of Health (Tarassud) from all health care institutions. A designated team will complete the epidemiological investigations within 24 hours to collect socio-demographics, onset date, risk factors, exposure and travel history, and clinical symptoms, with details of all possible contacts. For workplace and dormitories cluster, the Rapid Response Teams (RRTs) were involved for cluster investigation to determine potential interactions and epidemiological links and for containment. Close contacts were kept under quarantine for 14 days starting from last exposure day to the confirmed case and tested only if they developed symptoms suggestive of COVID-19.

\subsection{Data Extraction Process}

The study is based on both epidemiological data collected by surveillance team and the RRTs. The data were extracted from databases (Tarassud and ARCGIS 
systems). This extracted data was cross-checked by two coauthors for errors and quality. If any conflicting information, it will be resolved based on feedback from the original data source. Information regarding preparedness and responses in the workplace setting was obtained from secondary sources that included audit reports and periodic review reports.

\subsection{Statistical Analysis}

Excel 2016 software was used for data entry. Statistical analysis was done using SPSS version 22.0 software. We analyzed demographic and clinical features of all cases of COVID-19 clusters, cluster size, cluster duration and other cluster characteristics. Inferences were drawn fixing statistical significance and $\leq 0.05$ and 95\% confidence intervals estimated wherever applicable.

\section{Results}

\subsection{Outbreak Description}

Overall 36,798 COVID-19 cases were confirmed in Muscat governorate from 24th February to 31st July 2020 and 14,895 (40.5\%) was belonging to clusters (Figure 1). 61\% of cases belonging to clusters were from Workplace-Dormitory (Organizational) related (9080 cases in 560 work related clusters) and rest family clusters (Figure 1). First work related cluster was identified in $1^{\text {st }}$ April 2020 in essential food supplies sector during complete lockdown period affecting 112 employees. Population groups confined to homes such as Females, Children, Adolescents and older aged individuals were infected in family clusters, as expected. Expatriates formed predominant group affected in workplace settings (Table 2). The ages of the affected individuals in the workplace clusters varied from 18 years to 75 years, with a mean of 36.9 year $(S D=9.08)$, in comparison to 1 year to 90 years and a mean of 32.69 years $(\mathrm{SD}=16.7)$ in family clusters. There was a significant difference noted in sociodemographic variables such as gender, age groups and nationality between the two cluster types (Table 2).

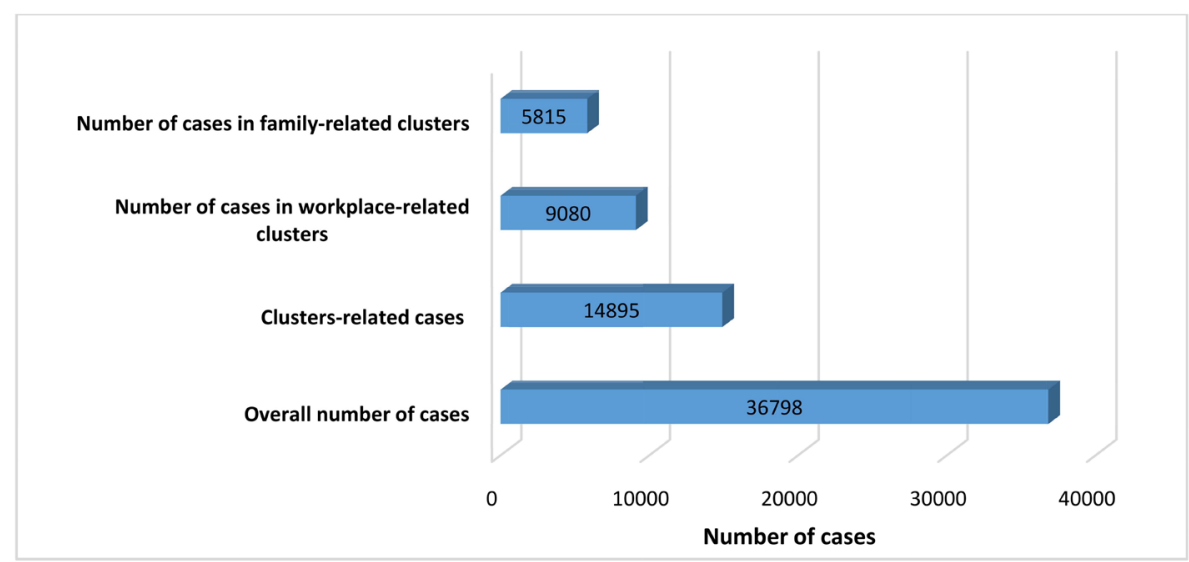

Figure 1. Prevalence of COVID-19 cases in Muscat Governorate during period Feb-July 2020. 
Table 2. Socio-demographic and clinical feature of cases in family and workplace related clusters in Muscat Governorate.

\begin{tabular}{|c|c|c|}
\hline & Family clusters & Workplace clusters \\
\hline & $\mathrm{N}(\%)$ & $\mathrm{N}(\%)$ \\
\hline Total cases & 5815 & 9080 \\
\hline \multicolumn{3}{|c|}{ Gender } \\
\hline Females & $2683(46.1)$ & $211(2.3)$ \\
\hline Males & $3132(53.9)$ & $8869(97.7)$ \\
\hline Mean age & 32.69 & 36.9 \\
\hline \multicolumn{3}{|c|}{ Age Groups } \\
\hline$\leq 20$ Years & $1334(22.9)$ & $28(0.3)$ \\
\hline 21 - 40 Years & $2858(49.1)$ & $5730(63.1)$ \\
\hline $41-60$ Years & $1227(21.1)$ & $2648(29.2)$ \\
\hline$>60$ Years & $314(5.4)$ & $94(1.0)$ \\
\hline Missing & $82(1.4)$ & $580(6.4)$ \\
\hline \multicolumn{3}{|c|}{ Nationality } \\
\hline Bangladeshi & $269(4.6)$ & $1241(13.7)$ \\
\hline Indian & $378(6.5)$ & $5992(66)$ \\
\hline Omani & $4651(80)$ & $607(6.7)$ \\
\hline Pakistani & $86(1.5)$ & $277(3.1)$ \\
\hline Other & $149(2.6)$ & $448(4.9)$ \\
\hline Missing & $283(4.9)$ & $515(5.7)$ \\
\hline \multicolumn{3}{|c|}{ Districts } \\
\hline Amerat & $1901(32.7)$ & $70(0.8)$ \\
\hline Bawshar & $821(14.1)$ & $3723(41)$ \\
\hline Muscat & $290(5)$ & $91(1)$ \\
\hline Mutrah & $1106(19)$ & $2115(23.3)$ \\
\hline Quriyat & $288(5)$ & $0(0)$ \\
\hline Seeb & $1409(24.2)$ & $3081(34)$ \\
\hline \multicolumn{3}{|c|}{ Symptomatic } \\
\hline Yes & $4983(85.7)$ & $7134(78.6)$ \\
\hline No & $622(10.7)$ & $1267(14)$ \\
\hline Missing & $211(3.6)$ & $679(7.5)$ \\
\hline \multicolumn{3}{|c|}{ Fever } \\
\hline Yes & $3187(54.8)$ & $4436(48.9)$ \\
\hline No & 2205 (37.9) & $3958(43.6)$ \\
\hline Missing & $424(7.3)$ & $686(7.6)$ \\
\hline
\end{tabular}




\section{Continued}

\begin{tabular}{|c|c|c|}
\hline \multicolumn{3}{|c|}{ Cough } \\
\hline Yes & $1967(33.8)$ & $2945(32.4)$ \\
\hline No & $3327(57.2)$ & $5449(60)$ \\
\hline Missing & $522(9.0)$ & $686(7.6)$ \\
\hline \multicolumn{3}{|c|}{ Shortness of breath } \\
\hline Yes & $231(4)$ & $482(5.3)$ \\
\hline No & $4537(78)$ & $7912(87.1)$ \\
\hline Missing & $1048(18.0)$ & $686(7.6)$ \\
\hline \multicolumn{3}{|c|}{ Sore throat } \\
\hline Yes & $1522(26.2)$ & $2354(25.9)$ \\
\hline No & 3717 (63.9) & $6040(66.5)$ \\
\hline Missing & 577 (9.9) & $686(7.6)$ \\
\hline \multicolumn{3}{|c|}{ Sneezing } \\
\hline Yes & $212(3.6)$ & $181(2)$ \\
\hline No & $4906(84.4)$ & $8213(90.5)$ \\
\hline Missing & $698(12.0)$ & $686(7.6)$ \\
\hline \multicolumn{3}{|c|}{ Runny nose } \\
\hline Yes & $1173(20.2)$ & $692(7.6)$ \\
\hline No & $3900(67.1)$ & $7702(84.8)$ \\
\hline Missing & $743(12.8)$ & $686(7.6)$ \\
\hline \multicolumn{3}{|c|}{ Anosmia } \\
\hline Yes & $295(5.1)$ & $253(2.8)$ \\
\hline No & $4692(80.7)$ & $8141(89.7)$ \\
\hline Missing & $829(14.3)$ & $686(7.6)$ \\
\hline \multicolumn{3}{|c|}{ Loss of taste } \\
\hline Yes & 457 (7.9) & $347(3.8)$ \\
\hline No & $4445(76.4)$ & 8047 (88.6) \\
\hline Missing & $914(15.7)$ & $686(7.6)$ \\
\hline \multicolumn{3}{|c|}{ Headache } \\
\hline Yes & $1089(18.7)$ & $1557(17.1)$ \\
\hline No & $3959(68.1)$ & $6837(75.3)$ \\
\hline Missing & $768(13.2)$ & $686(7.6)$ \\
\hline \multicolumn{3}{|c|}{ Diarrhea } \\
\hline Yes & $242(4.2)$ & $8242(90.8)$ \\
\hline No & $4592(79)$ & $152(1.7)$ \\
\hline Missing & $982(16.9)$ & $686(7.6)$ \\
\hline
\end{tabular}




\section{Continued}

\begin{tabular}{|c|c|c|}
\hline \multicolumn{3}{|c|}{ Diabetes Mellitus } \\
\hline Yes & $366(6.3)$ & $309(3.4)$ \\
\hline No & $4314(74.2)$ & $7554(83.2)$ \\
\hline Missing & $1136(19.5)$ & $1217(13.4)$ \\
\hline \multicolumn{3}{|c|}{ Hypertension } \\
\hline Yes & $350(6.0)$ & $269(3)$ \\
\hline No & $4328(74.4)$ & $7594(83.6)$ \\
\hline Missing & $1138(19.6)$ & $1217(13.4)$ \\
\hline \multicolumn{3}{|c|}{ Obesity } \\
\hline Yes & $86(1.5)$ & $19(0.2)$ \\
\hline No & $4584(78.8)$ & $7844(86.4)$ \\
\hline Missing & $1134(19.5)$ & $1217(13.4)$ \\
\hline \multicolumn{3}{|c|}{ Smoking } \\
\hline Yes & $205(3.5)$ & $286(3.1)$ \\
\hline No & $4477(77)$ & $7577(83.4)$ \\
\hline Missing & $1140(19.6)$ & $1217(13.4)$ \\
\hline \multicolumn{3}{|c|}{ Alcohol consumption } \\
\hline Yes & $15(0.3)$ & $139(1.5)$ \\
\hline No & $4661(80.1)$ & $7724(85.1)$ \\
\hline Missing & $1146(19.7)$ & $1217(13.4)$ \\
\hline
\end{tabular}

\subsection{Epidemic Curve}

Epidemic curves, week wise were plotted (Figure 2) utilizing onset dates of clustered cases, showed that work related cases curve followed the pattern of overall curve. Although family clusters preceded, work related clusters exceeded much more than family clusters in the later phase (Figure 2). Overall peak of confirmed cases coincided with the peak number of work-related clusters. Figure 3 shows the settings of work related clusters and their pattern in the epi-curve. Services, food \& beverages and retail were major contributors of the first peak whereas for the second peak it was construction sector, retail, industrial manufacturing and food \& beverages industries. Bawshar, Mutrah and Seeb districts with most organizations located naturally showed maximum clusters in the second peak that occurred in post lockdown phase (Figure 4), Mutrah and Bawshar districts had clusters in lockdown phase also. Figure 5 shows that different sizes of clusters occurred throughout the pandemic.

\subsection{Cluster Characteristics}

Overall, the number of affected employees ranged from 2 to 358 per cluster. 


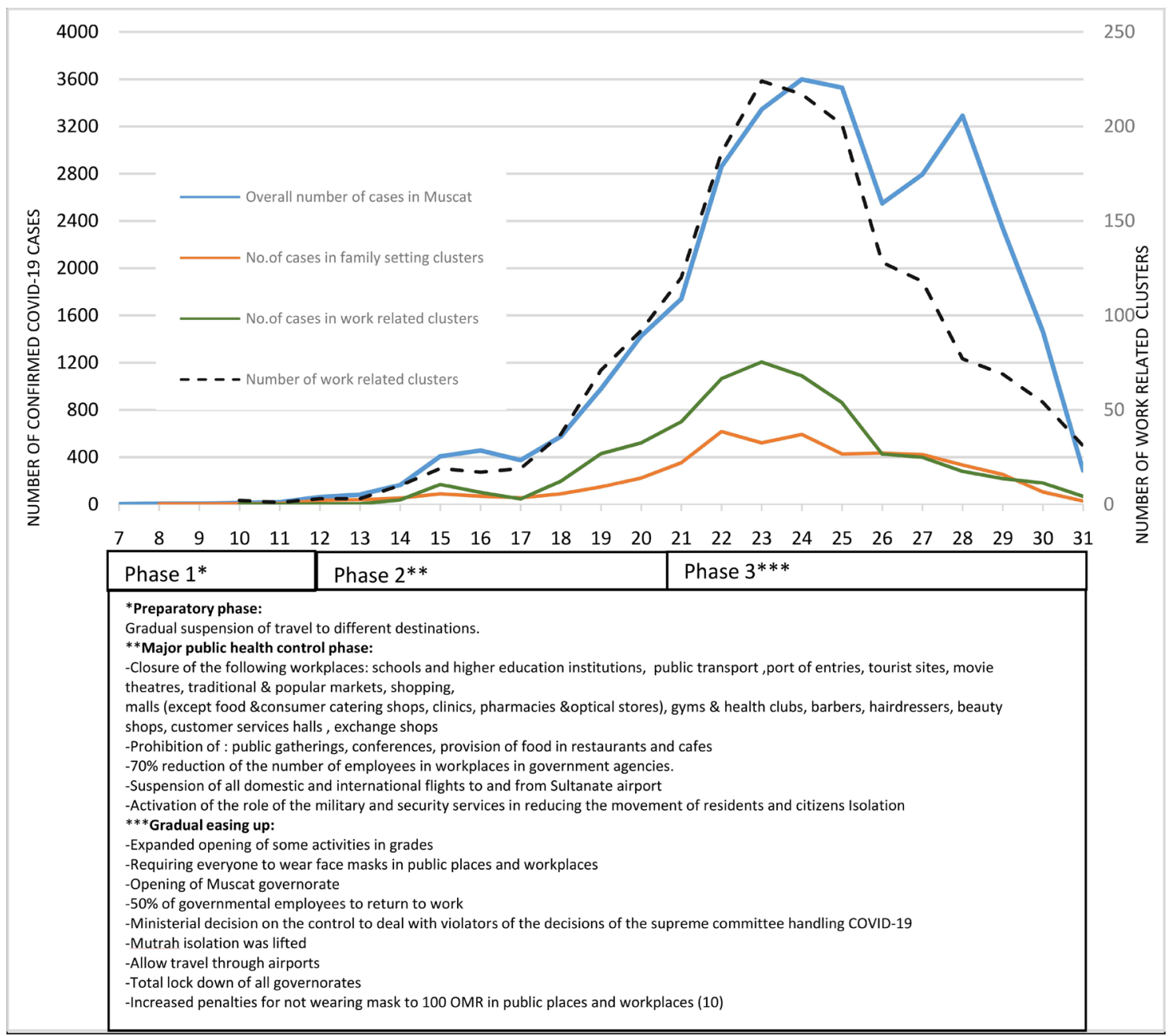

Figure 2. Epidemiological curves of confirmed COVID-19 cases \& clusters in Muscat Governorate during period Feb-July 2020.

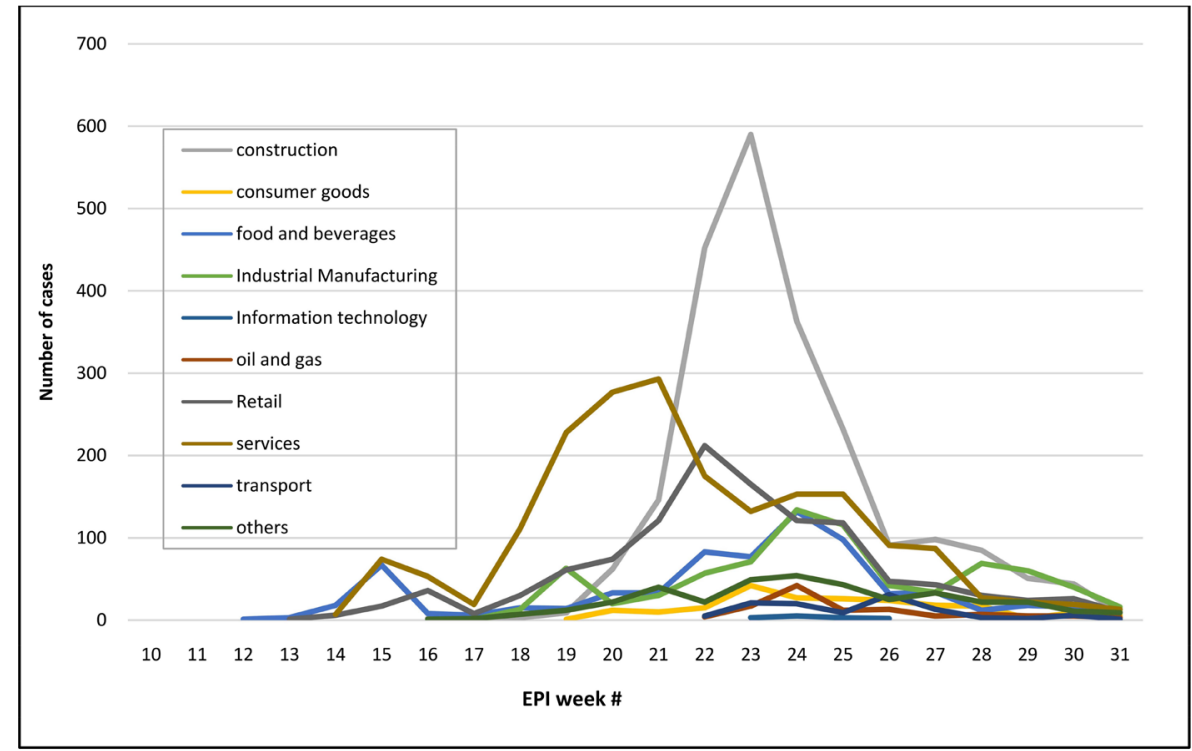

Figure 3. Epicurve of cases in workplace-related clusters based on setting. 


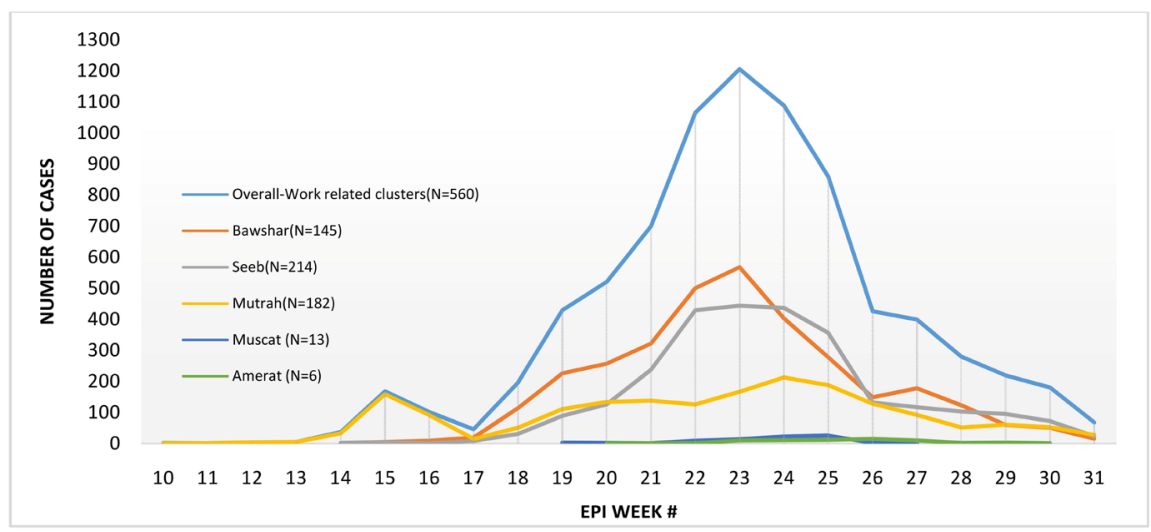

Figure 4. Epicurves of cases in Work-related clusters by Districts. (Number of clusters/district mentioned in brackets in legend).

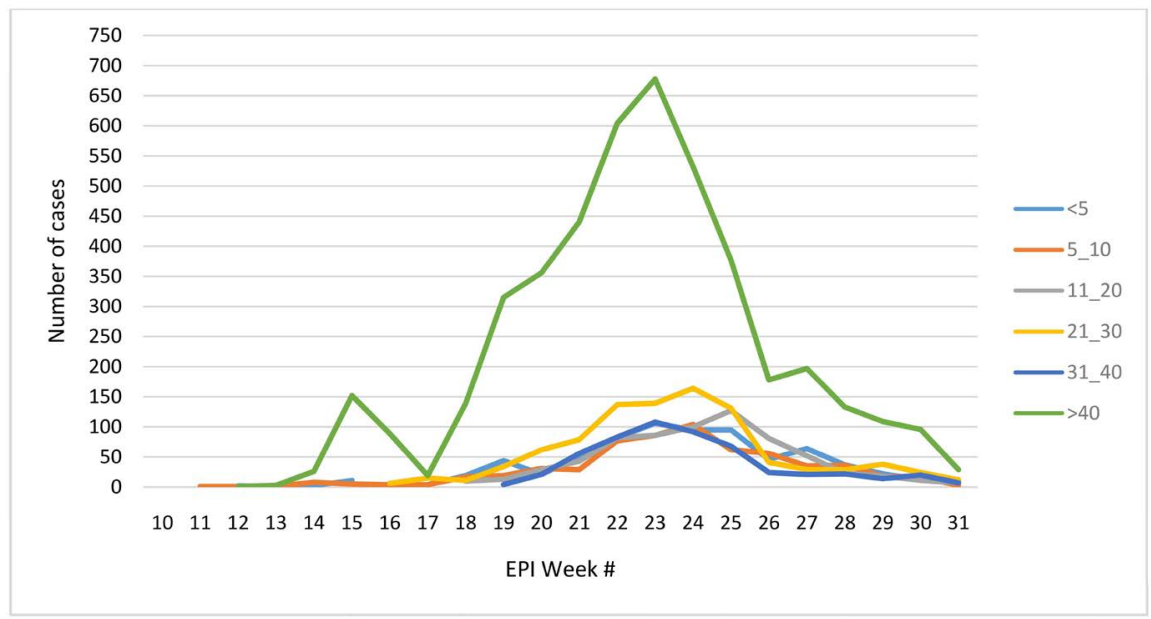

Figure 5. Epidemiological curves of work related cluster by size of cluster.

Majority of clusters had $<5$ cases (299) and 54 had more than 40 cases, the large sized mostly organizations with dormitories for workers (Figure 6). Construction, Services, Food \& beverage, Manufacturing sectors in that descending order (17, 15, 6 and 6 clusters respectively) were the most common sectors reporting large sized outbreaks. Median duration of outbreaks in workplace-related clusters (From onset date of index case to that of last case) was 8.5 days (Range $1-113, \mathrm{IQR}=23.5)$. In terms of incidence density of clusters and cases construction sector was the most affected one during this outbreak. Apart from this Retail, Food \& beverages, Services and Manufacturing sectors were most affected. More clusters were noted in manufacturing industries sector and more cases were noted in Retail sector compared to others (Figure 7 \& Figure 8).

With reference to date of initial investigation of cluster, it was found that $8 \%$ (651/8081) developed symptoms within 7 days of this investigation. 26\% (2103/8081) reported onset within 24 hours prior to time of investigation. Majority of the cases (7696/8081) in occupational clusters had symptoms within a week of the initial investigation or initial case reporting. 


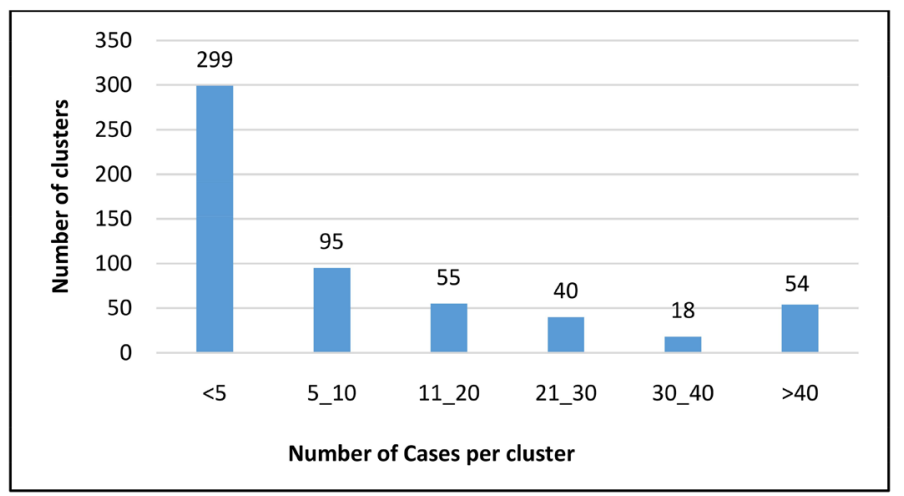

Figure 6. Number of cases per cluster (work related).

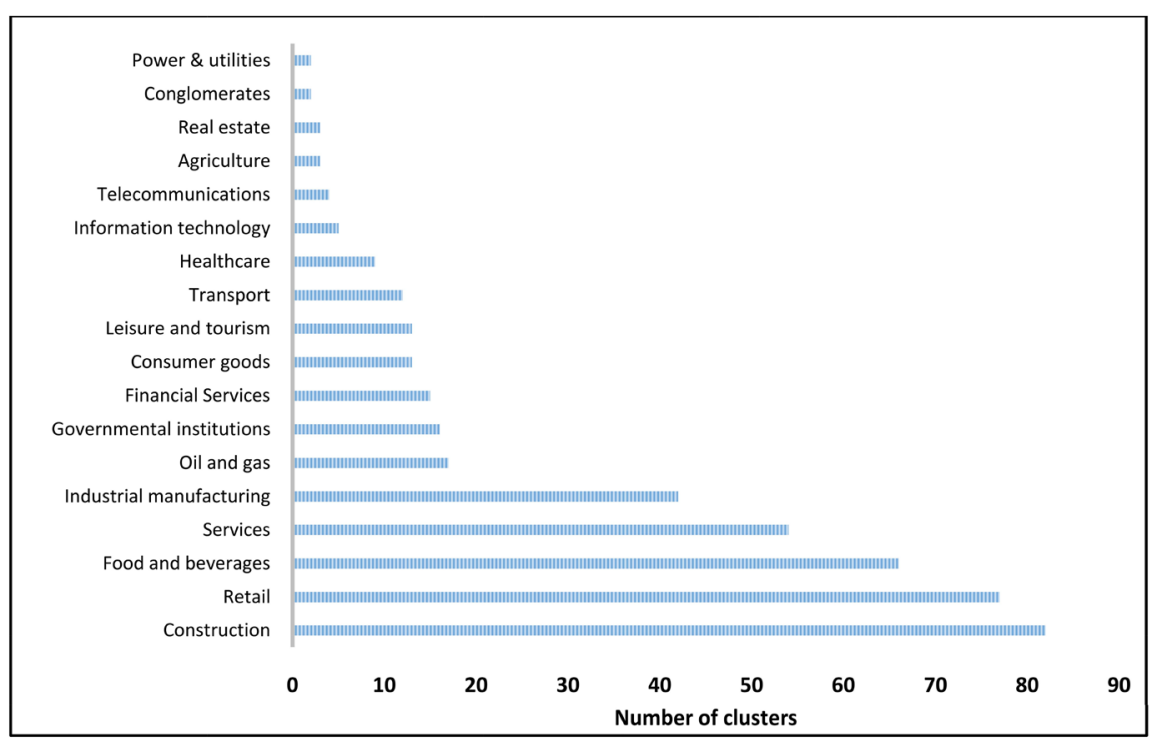

Figure 7. Number of work related clusters by sector/industry type.

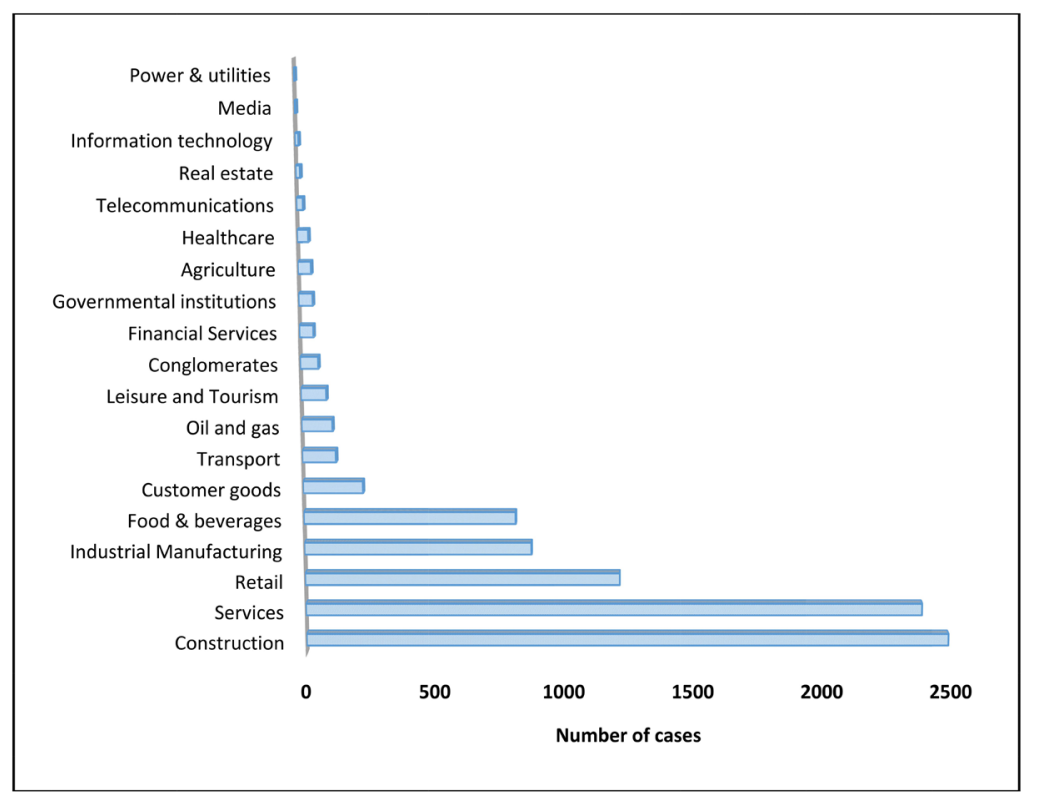

Figure 8. Number of cases by type of sector/industry among work related clusters. 


\subsection{Clinical Characteristics of Cases in Organizational Clusters}

Among the workplace and dormitories clusters, $78.6 \%$ of employees were symptomatic whereas $14 \%$ were asymptomatic at time of examination (Table 2). Fever and cough were the two most common symptoms, reported in workplace and dormitories clusters and the details are given in Table 2. 2118 employees reported other symptoms like weakness, loss of appetite, vomiting, abdominal pain etc.

Diabetes and hypertension were the most common risk factors noted among affected employees, whereas smoking, alcohol consumption and obesity were other risk factors as shown in Table 2. Within the cases in workplace-related clusters, there was significant higher prevalence of diabetes, hypertension and obesity among females compared to males as also Omani nationals compared to expatriates and smoking among expatriate males compared to Omani males Table 3.

\section{Discussion}

Workplace and dormitories setting outbreaks contributed significantly to the overall COVID-19 burden with the majority of industries and commercial activities being located in the Governorate [12]. COVID-19 clusters in Muscat started in families followed later by workplace-related clusters except for one initial occupational cluster in Mutrah district. This could be due to early institutions of restrictions in Muscat Governorate that limited occupational exposures except in essential services sector. Work related epi-curve followed in general with that of the Governorate indicating the important role played by such settings in the spread of the pandemic. This aspect has been highlighted in most of the early reports on epidemiology of COVID-19 from other countries [14] [15].

Table 3. Risk factors among COVID 19 cases in work related clusters.

\begin{tabular}{|c|c|c|c|c|c|c|c|c|}
\hline Variables & $\begin{array}{c}\text { Diabetes } \\
\mathrm{N}(\%)\end{array}$ & $\begin{array}{c}\chi^{2} \\
(p \text { value })\end{array}$ & $\begin{array}{l}\text { HTN }^{\$} \\
\text { N (\%) }\end{array}$ & $\begin{array}{c}\chi^{2} \\
(p \text { value })\end{array}$ & $\begin{array}{l}\text { Obesity } \\
\text { N (\%) }\end{array}$ & $\begin{array}{c}\chi^{2} \\
(p \text { value })\end{array}$ & $\begin{array}{c}\text { Smoking } \\
\mathrm{N}(\%)\end{array}$ & $\begin{array}{c}\chi^{2} \\
(p \text { value })\end{array}$ \\
\hline Males & $491(4.8)$ & \multirow{3}{*}{$55.9(p<0.001)$} & $418(4.1)$ & \multirow{3}{*}{$86.09(p<0.001)$} & $56(.5)$ & & $433(4.2)$ & \multirow{3}{*}{$21.8(p<0.001)$} \\
\hline & & & & & & $54.9(p<0.001)$ & & \\
\hline Females & $204(8.7)$ & & $204(8.7)$ & & $105(.8)$ & & $51(2.2)$ & \\
\hline Omani & $348(8.1)$ & \multirow{3}{*}{$82.7(p<0.001)$} & $335(7.8)$ & \multirow{3}{*}{$112.9(p<0.001)$} & $89(2.1)$ & \multirow{3}{*}{$120.5(p<0.001)$} & $136(3.2)$ & \multirow{3}{*}{$8.23(p=0.004)$} \\
\hline & & & & & & & & \\
\hline Expatriates & $347(5.5)$ & & $287(3.5)$ & & $16(0.2)$ & & $348(4.2)$ & \\
\hline$\leq 20$ Years & $27(2.4)$ & \multirow{4}{*}{$600.7^{*}(p<0.001)$} & $10(0.9)$ & \multirow{4}{*}{$1014.8^{\star}(p<0.001)$} & $7(0.6)$ & \multirow{4}{*}{$23.6^{*}(p<0.001)$} & $25(2.2)$ & \multirow{5}{*}{$0.056^{\star}(p=0.813)$} \\
\hline \multirow[t]{2}{*}{21 - 40 Years } & $171(2.3)$ & & $125(1.7)$ & & $52(0.7)$ & & $319(4.2)$ & \\
\hline & & & & & & & & \\
\hline $41-60$ Years & $382(10.8)$ & & $365(10.3)$ & & $35(1.0)$ & & $130(3.7)$ & \\
\hline$>60$ Years & $115(30.7)$ & & $122(32.8)$ & & $11(3.0)$ & & $10(2.7)$ & \\
\hline
\end{tabular}

* Linear-by-linear association (chi-square test for trend), \$ Hypertension. 
More than $87 \%$ of cases in workplace related clusters during the period of this study were migrants (66\% were Indian migrants). Larger clusters were noted in occupational settings with dormitories. Most workers in dormitories were blue collar migrants from India with much less proportion from other countries. Most of these dormitory settings were having far from satisfactory living conditions and per capita space. This is also one reason that resulted in our study showing huge male preponderance in work related clusters. As stated before many studies have highlighted the risk of spread of disease among migrant populations and factors responsible which was reflected in our results [7] [16] [17] [18]. The issue of migrant health in general and specifically in occupational settings need to be considered seriously for future public health intervention. Also, as migrants will need to go to their home-countries and return, it may create higher risk for transmission in organizational settings and it may not be feasible to make vaccine readily available for every one or for mandatory pre-travel vaccination [17].

Clusters from organizational-setting are more in Bawshar, Seeb and Mutrah due to high densities of companies and dormitories in these districts. Mutrah was the first district with community spread in Oman that resulted in the first peak of epidemic and was under lockdown from March end to July. The investigation and follow up of initial organizational clusters in Mutrah facilitated identification of early cases linked to these organizations in other districts. It is important track clusters and possible links to other in epidemics not only from the point of view of early detection and containment but also in terms of distribution of resources that become scarce in epidemic settings.

Construction, retail, food, beverages, services, industrial manufacturing, oil \& gas and transportation were identified as most at risk settings. Some of these were essential services or critical industries, which remain functioning during the pandemic. Although these two groups were well targeted during the pre-pandemic preparedness except for oil and gas industry, not much impact was seen in the initial phase of the pandemic. As noted before it is common practice in many organizations in Muscat governorate to provide shared most often overcrowded accommodation, shared transportation and shared facilities for workers all of which were major contributing factors to COVID-19 transmission in these sectors. These findings are similar to reports from other countries too [18] [19]. Many countries reported affected categories like those working in grocery stores, transportation services, warehouse, construction, and retail, restaurants, domestic workers, security guards and delivery services [3] [5] [6] [17]. Flight and ship crews are also at risk of exposure due to contact with infected passengers [7].

Fever and cough were most common presentation and diabetes, hypertension and smoking are most common risk factors among employees involved in organization-setting outbreak, which is not different from the overall patients' presentation in Muscat as reported by Al Balushi et al. [16]. This indicates the 
importance of efficient fever scanning (thermal screening)/symptom screening at workplaces for early detection of suspected cases. We also found $15 \%$ were asymptomatic at time of examination, which also indicate the importance of complying with the protection measure at workplaces to prevent spread of the disease from asymptomatic colleagues as asymptomatic carriers can be a latent source of COVID-19 infection leading to propagation of the outbreak and impeding infection control [20] [21].

In this study, we found that majority of cases in organizational clusters tested positive within a week of the initial investigation or initial case reporting. It is possible that there is delayed reporting of initial case for testing which indicates the difficulty in early case identification and isolating. This behavior of reporting to work "Presenteeism" [17] despite being symptomatic does lead to spread of infection. Asymptomatic transmission, mild illness etc. and psychological impact of wage losses are issues of importance in occupational settings. We also found that around $8 \%$ of them tested for COVID-19 before onset date possibly because of mass screening by employers or panic testing.

We also found that Omanis reported more diabetes, hypertension and obesity than residents which could be due to the high prevalence of diabetes [22], hypertension [23] and obesity [24] among the Omani population vis a vis migrant population with younger mean age. Workers who are having underlying chronic diseases run severe course of the disease caused by COVID-19 and should be considered when planning any preventive and control measures for COVID-19 in the workplace [7].

Limitations: This study analyzed data from work related clusters during the initial phase of the pandemic. The study did not analyze the links to interventions done at various stages of the pandemic and hence did not attempt to bring effectiveness of measures adopted.

\section{Conclusions}

This analysis of COVID-19 clustering pattern in organization setting in Muscat Governorate provides insight into the natural history, transmission, key characteristic features and gives an evidentiary foundation for predicting the impact of the virus in Oman, which is important in guiding the national public health response. In conclusion, COVID-19 pandemic is a new experience in Oman and understanding the epidemiological characteristics of the affected cases in organization-setting will assist the policymakers to understand patterns of epidemiological spread and thus plan for robust interventions.

Based on this paper finding, in order to reduce the influence of COVID-19 in Oman, workplaces need to be well prepared to deal with this pandemic and be predictive and proactive in their plans and decisions for preserving business continuity. High risk employees, occupations and living environments need to be considered in every organization's preparedness and control plan for COVID-19. 


\section{Funding Source}

This research received no external funding.

\section{Ethical Approval}

Ethical approval granted from Directorate General of Health Services-Muscat.

\section{Acknowledgements}

The authors wish to thank all members of the rapid response team, healthcare institutions and COVID-19 focal points in Muscat governorate for their collaboration and assistance.

\section{Conflicts of Interest}

The authors declare no conflicts of interest regarding the publication of this paper.

\section{References}

[1] Gao, Y., Shi, C., Chen, Y., Shi, P., Liu, J., Xiao, Y., et al. (2020) A Cluster of the Corona Virus Disease 2019 Caused by Incubation Period Transmission in Wuxi, China. Journal of Infection, 80, 666-670. https://doi.org/10.1016/j.jinf.2020.03.042

[2] Zhang, J., Litvinova, M., Wang, W., Wang, Y., Deng, X., Chen, X., et al. (2020) Evolving Epidemiology and Transmission Dynamics of Coronavirus Disease 2019 Outside Hubei Province, China: A Descriptive and Modeling Study. The Lancet Infectious Diseases, 20, 793-802. https://doi.org/10.1016/S1473-3099(20)30230-9

[3] Furuse, Y., Sando, E., Tsuchiya, N., Miyahara, R., Yasuda, I., Ko, Y.K., et al. (2020) Clusters of Coronavirus Disease in Communities, Japan, January-April 2020. Emerging Infectious Diseases, 26, 2176-2179. https://doi.org/10.3201/eid2609.202272

[4] Saidan, M.N., Shbool, M.A., Arabeyyat, O.S., Al-Shihabi, S.T., Al Abdallat, Y., Barghash, M.A., et al. (2020) Estimation of the Probable Outbreak Size of Novel Coronavirus (COVID-19) in Social Gathering Events and Industrial Activities. International Journal of Infectious Diseases, 98, 321-327. https://doi.org/10.1016/j.ijid.2020.06.105

[5] Dennerlein, J.T., Burke, L., Sabbath, E.L., Williams, J.A.R., Peters, S.E., Wallace, L., et al. (2020) An Integrative Total Worker Health Framework for Keeping Workers Safe and Healthy During the COVID-19 Pandemic. Human Factors. The Journal of the Human Factors and Ergonomics Society, 62, 689-696.

[6] Baker, M.G., Peckham, T.K. and Seixas, N.S. (2020) Estimating the Burden of United States Workers Exposed to Infection or Disease: A Key Factor in Containing Risk of COVID-19 Infection. PLoS ONE, 15, e0232452.

https://doi.org/10.1371/journal.pone.0232452

[7] Gobabaei, F. and Kalantari, S. (2020) A Review of the Strategies and Policies for the Prevention and Control of the COVID-19 at Workplaces. International Journal of Occupational Hygiene, 12, 60-65.

[8] Ministry of Health, Directorate General of Disease Surveillance \& Control (2020) A Guide to the Precautionary Measures Followed to Deal with Covid-19 Disease Out- 
breaks in Facilities and Dormitories. Ministry of Health, Muscat.

[9] Ministry of Health and Ministry of Manpower (2020) Measures to Be Followed by Companies and Sponsors to Limit the Spread of Covid-19 Disease among Workers. Ministry of Health, Ministry of Manpower, Muscat.

[10] Al Wahaibi, A., Al Manji, A., Al Maani, A., Al Rawahi, B., Al Harthy, K., Alyaquobi, F., et al. (2020) COVID-19 Epidemic Monitoring after Non-Pharmaceutical Interventions: The Use of Time-Varying Reproduction Number in a Country with a Large Migrant Population. International Journal of Infectious Diseases, 99, 466-472.

[11] Magnusson, K., Nygård, K., Methi, F., Vold, L. and Telle, K. (2020) Occupational Risk of COVID-19 in the $1^{\text {st }}$ vs $2^{\text {nd }}$ Wave of Infection. medRxiv.

[12] National Center for Safety Initiatives (2020) Development Indicators. https://ncsi.gov.om/Pages/NCSI.aspx

[13] Ministry of Health (2020) Navigation. Health Care Workers Section. https://www.moh.gov.om/en/-56

[14] Tariq, A., Lee, Y., Roosa, K., Blumberg, S., Yan, P., Ma, S., et al. (2020) Real-Time Monitoring the Transmission Potential of COVID-19 in Singapore, February 2020. BMC Medicine, 18, Article No. 166. https://doi.org/10.1186/s12916-020-01615-9

[15] Shim, E., Tariq, A., Choi, W., Lee, Y. and Chowell, G. (2020) Transmission Potential and Severity of COVID-19 in South Korea. International Journal of Infectious Diseases, 93, 339-344. https://doi.org/10.1016/j.ijid.2020.03.031

[16] Al Balushi, L., Al Fahdi, F., Al Ghafri, T., Amin, M., Singh, J., Al Siyabi, B., et al. (2021) Epidemiological Characteristics of COVID-19 Confirmed Cases in Muscat Governorate, Sultanate of Oman. Open Journal of Epidemiology, 11, 56-69. https://doi.org/10.4236/ojepi.2021.111006

[17] European Centre for Disease Prevention and Control (2020) COVID-19 Clusters and Outbreaks in Occupational Settings in the EU/EEA and the UK. European Centre for Disease Prevention and Control, Solna Municipality.

https://www.ecdc.europa.eu/en/publications-data/covid-19-clusters-and-outbreaksoccupational-settings-eueea-and-uk

[18] Coyle, P.V., Chemaitelly, H., Hadj Kacem, M.A., Hassan Abdulla Al Molawi, N., Awni El Kahlout, R., Gilliani, I., et al. (2021) SARS-CoV-2 Seroprevalence in the Urban Population of Qatar: An Analysis of Antibody Testing on a Sample of 112,941 Individuals. medRxiv. https://doi.org/10.1101/2021.01.05.21249247

[19] Pandoman, A. (2020) Analisis Quietus Politik Terhadap Upaya Pemerintah Menangani Wabah Covid-19 Pasca Deklarasi Public Health Emergency of International Concern (PHEIC). Ulumuddin: Jurnal Ilmuilmu Keislaman, 10, 1-12. https://doi.org/10.47200/ulumuddin.v10i1.379

[20] Bi, Q., Wu, Y., Mei, S., Ye, C., Zou, X., Zhang, Z., et al. (2020) Epidemiology and Transmission of COVID-19 in 391 Cases and 1286 of Their Close Contacts in Shenzhen, China: A Retrospective Cohort Study. The Lancet Infectious Diseases, 20, 911-919. https://doi.org/10.1016/S1473-3099(20)30287-5

[21] Ye, F., Xu, S., Rong, Z., Xu, R., Liu, X., Deng, P., et al. (2020) Delivery of Infection from Asymptomatic Carriers of COVID-19 in a Familial Cluster. International Journal of Infectious Diseases, 94, 133-138.

https://doi.org/10.1016/j.ijid.2020.03.042

[22] Khandekar, R.B. and Al-Lawati, J.A. (2015) Epidemiology of Diabetic Retinopathy in Oman: Two Decades of Research. Oman Journal of Ophthalmology, 8, 1-2. 
[23] Al Riyami, A.A. and Afifi, M.M. (2002) Hypertension in Oman: Distribution and Correlates. Journal of the Egyptian Public Health Association, 77, 383-407.

[24] Al-Riyami, A.A. and Afifi, M.M. (2003) Prevalence and Correlates of Obesity and Central Obesity among Omani Adults. Saudi Medical Journal, 24, 641-646. 